\title{
Down-regulation of miR-125a-3p in human gastric cancer and its clinicopathological significance
}

\author{
YOJIRO HASHIGUCHI $^{1 *}$, NAOHIRO NISHIDA $^{2,3^{*}}$, KOSHI MIMORI $^{2}$, TOMOYA SUDO $^{2}$, \\ FUMIAKI TANAKA $^{2}$, KOHEI SHIBATA ${ }^{2}$, HIDESHI ISHII ${ }^{2,3}$, HIDETAKA MOCHIZUKI $^{1}$, \\ KAZUO HASE $^{1}$, YUICHIRO DOKI ${ }^{3}$ and MASAKI MORI ${ }^{3}$
}

\author{
${ }^{1}$ Department of Surgery, National Defense Medical College, 3-2 Namiki, Tokorozawa, Saitama 359-8513; \\ ${ }^{2}$ Department of Surgery and Molecular Oncology, Medical Institute of Bioregulation, Kyushu University, \\ 4546 Tsurumibaru, Beppu, Oita 874-0838; ${ }^{3}$ Department of Gastroenterological Surgery, Osaka University \\ Graduate School of Medicine, 2-2 Yamada-oka, Suita, Osaka 565-0871, Japan
}

Received October 11, 2011; Accepted December 9, 2011

DOI: 10.3892/ijo.2012.1363

\begin{abstract}
Recent reports have demonstrated that another strand of mature microRNA (miRNA), called microRNA* or 3p (5p) strand, which is generated from the same precursor miRNA (Pre-miR), has a crucial role in cellular function. We previously reported the tumor suppressive effect of $m i R-125 a-5 p$ in gastric cancer. The current study was designed to examine the function and clinical significance of $m i R-125 a-3 p$, a partner strand of $m i R-125 a-5 p$, in human gastric cancer. Quantitative RT-PCR was used to evaluate $m i R-125 a-3 p$ expression in 70 gastric cancer cases to determine the clinicopathologic significance of $m i R-125 a-3 p$ expression. In addition, the effect of $m i R-125 a-3 p$ on the proliferation of gastric cancer cells was investigated. Low expression levels of $m i R-125 a-3 p$ were associated with indicators of enhanced malignant potential such as tumor size ( $\mathrm{p}=0.0002$ ), tumor invasion $(\mathrm{p}=0.0149)$, lymph node metastasis $(\mathrm{p}=0.018)$, liver metastasis $(\mathrm{p}=0.016)$, peritoneal dissemination $(\mathrm{p}=0.03)$, advanced clinical stage $(\mathrm{p}=0.0037)$ and poor prognosis $(\mathrm{p}=0.0083)$. Multivariate analysis indicated that low miR-125a-3p expression was an independent prognostic factor for survival, while in vitro assays demonstrated that $m i R-125 a-3 p$ suppressed the proliferation of gastric cancer cells. MiR-125a-3p is a potent prognostic marker in gastric cancer. The clinical significance and tumor suppressive effect of $m i R-125 a-3 p$, as well as previously reported $m i R-125 a-5 p$, suggest that the functional role of another strand of the mature form miRNA cannot be ignored, at least in miR-125a biogenesis.
\end{abstract}

Correspondence to: Professor Masaki Mori, Department of Gastroenterological Surgery, Osaka University Graduate School of Medicine, 2-2 Yamada-oka, Suita, Osaka 565-0871, Japan

E-mail: mmori@gesurg.med.osaka-u.ac.jp

"Contributed equally

Key words: microRNA, miR-125a-3p, partner strand, clinical significance

\section{Introduction}

Gastric cancer is one of the most common cancers in Asian countries, including China, Korea and Japan. In Japan, over fifty thousand new cases are diagnosed each year. It is the leading cause of malignancies in males, the second leading cause in females, and the second largest cause of cancer mortality in both male and female $(1,2)$. 5 -fluorouracil (5-FU)-based adjuvant or neoadjuvant chemotherapy improved the 5 -year overall survival rate to more than $50 \%$ in stage I-III patients. However, advanced cases with peritoneal dissemination or distant metastasis cannot be controlled, and the 5-year overall survival rate of stage IV patients is under 10\% (3). In these advanced cases, molecular targeted therapy including trastuzumab, a monoclonal antibody against the ERBB2 gene, is now in clinical use, and molecular targeted therapy is considered as a promising new strategy against gastric cancer (4).

Alternations in miRNA expression have been implicated in the initiation, progression, and metastasis of a number of human cancers (5). miRNAs constitute a class of small (19-25 nucleotides), non-coding RNAs that function as post-transcriptional gene regulators (6-8). In gastric cancer, oncogenic miRNAs such as the $m i R-93-106 b$ cluster and $m i R-21$, are associated with cancer progression (9-14), and targeted therapy against these miRNAs is under development. Previously, we demonstrated the tumor suppressive effect of $m i R-125 a-5 p$ in human gastric cancer (10).

In the current study, we focused on $m i R-125 a-3 p$, which is generated as another strand of $m i R-125 a-5 p$ in the maturation process from precursor double strand RNA (pre-miRNA). Another strand of mature form miRNA, called microRNA* strand species or $3 p(5 p)$ strand, has been regarded as a passenger strand and not been extensively investigated. However, recent reports indicate that a substantial fraction of microRNA* strand species is broadly conserved among vertebrates, and that it might have cellular functions $(15,16)$. Thus, the influence of both strands should be considered when predicting the behavior of individual miRNAs. Very few reports have demonstrated the contribution of both strands to cancer progression. Here 
we show the clinical significance and biological function of $m i R-125 a-3 p$, a partner of $m i R-125 a-5 p$, whose tumor suppressive effect has been demonstrated in gastric cancer.

\section{Materials and methods}

\section{Clinical cases}

Patients and sample collection. Seventy gastric cancer and paired normal gastric tissue samples were obtained during surgery and used after obtaining informed consent. All patients underwent resection of the primary tumor at Kyushu University Hospital at Beppu and affiliated hospitals between 1992 and 2000. All patients had a clear histological diagnosis of gastric cancer, based on the clinicopathologic criteria described by the Japanese Gastric Cancer Association (17), and were closely followed every 3 months. The follow-up periods ranged from 0.2 months to 12.3 years, with a mean of 2.6 years. Resected cancer tissues were immediately cut and embedded in TissueTek OCT medium (Sakura), frozen in liquid nitrogen, and kept at $-80^{\circ} \mathrm{C}$ until RNA and DNA extraction. Frozen tissue specimens were homogenized in guanidium thiocyanate, and total RNA was obtained by ultracentrifugation through a cesium chloride cushion. cDNA was synthesized from $8.0 \mu \mathrm{g}$ of total RNA as previously described (18). Clinicopathological factors and clinical stages were classified by the criteria of the Japanese Gastric Cancer Association (17). All sample data, including age, gender, tumor size and depth, lymphatic invasion, lymph node metastasis, vascular invasion, liver metastasis, peritoneal dissemination, distant metastasis, clinical stage and histological grade were obtained from the clinical and pathologic records, and are summarized in Table I. Written informed consent for study participation was obtained from all patients.

Evaluation of miR-125a-3p and miR-125a-5p expression in clinical samples. For miR-125a-3p and miR-125a-5p quantitative real-time reverse transcriptase-polymerase chain reaction (RT-PCR), cDNA was synthesized from $10 \mathrm{ng}$ of total RNA using TaqMan ${ }^{\mathrm{TM}}$ MicroRNA $h s a-m i R-125 a-3 p$ and $h s a-m i R-$ $125 a-5 p$ specific primers (Applied Biosystems) and a TaqMan ${ }^{\text {TM }}$ MicroRNA Reverse Transcription Kit (Applied Biosystems). The following temperature profile was used: initial denaturation at $95^{\circ} \mathrm{C}$ for $10 \mathrm{~min}$, followed by 45 cycles of denaturation at $95^{\circ} \mathrm{C}$ for $10 \mathrm{sec}$, annealing at $60^{\circ} \mathrm{C}$ for $10 \mathrm{sec}$, and extension at $65^{\circ} \mathrm{C}$ for $10 \mathrm{sec} . \mathrm{PCR}$ was performed in a LightCycler ${ }^{\mathrm{TM}} 480$ System (Roche Applied Science) using the LightCycler ${ }^{\mathrm{TM}} 480$ Probes Master Kit (Roche Applied Science). Expression levels of $m i R-125 a-3 p$ were normalized to that of the small nuclear RNA RNU6B (Applied Biosystems) transcript. Each assay was performed three times to verify the results, and the mean normalized value of mRNA expression was used for subsequent analyses.

\section{Experimental studies}

Cell lines and cell culture. The human gastric cancer cell lines MKN7 and NUGC4 were provided by the Cell Resource Center of Biomedical Research, Institute of Development, Aging and Cancer, Tohoku University. These cell lines were cultured in a humidified 5\% $\mathrm{CO}_{2}$ incubator at $37^{\circ} \mathrm{C}$ using RPMI-1640 supplemented with $10 \%$ fetal bovine serum, 100 units $/ \mathrm{ml}$ penicillin, and 100 units $/ \mathrm{ml}$ streptomycin sulfates.
Table I. miR-125a-3p expression and clinicopathological factors.

\begin{tabular}{lrrrr}
\hline & $\begin{array}{r}\text { Tumor } \\
\text { low exp. } \\
(\mathrm{n}=35)\end{array}$ & $\begin{array}{c}\text { Tumor } \\
\text { high exp. } \\
(\mathrm{n}=35)\end{array}$ & \\
${$\cline { 2 - 2 }$} }$ & No. $(\%)$ & No. $(\%)$ & p-value \\
\hline Age (mean \pm SD) & $64.9 \pm 2.08$ & $65.0 \pm 2.08$ & 0.95 \\
$\begin{array}{l}\text { Sex } \\
\text { Male }\end{array}$ & $26(74.3)$ & $22(62.9)$ & 0.30 \\
Female & $9(25.7)$ & $13(37.1)$ &
\end{tabular}

Histological grade

$\begin{array}{lllll}\text { Well } & 15(74.3) & 19(52.8) & 0.40 \\ \text { Moderately, poorly } & 20(25.7) & 16 & (47.2) & \end{array}$

Moderately, poorly $20(25.7) \quad 16(47.2)$

Size

$\begin{array}{lrllll}<50 \mathrm{~mm} \text { (small) } & 8 & (34.3) & 23 & (65.7) & 0.0002^{\mathrm{b}} \\ >51 \mathrm{~mm} \text { (large) } & 27 & (65.7) & 12 & (34.3) & \end{array}$

Depth of tumor invasion ${ }^{\mathrm{a}}$

\begin{tabular}{|c|c|c|}
\hline $\mathrm{m}, \mathrm{sm}, \mathrm{mp}, \mathrm{ss}$ & $15(42.9)$ & $25(71.4)$ \\
\hline se, si & $20(57.1)$ & $10(28.6)$ \\
\hline
\end{tabular}

Lymph node metastasis

Absent

$6(17.1) \quad 15(42.9) \quad 0.0018^{\mathrm{b}}$

Present

$29(82.9) \quad 20(57.1)$

Lymphatic invasion

$\begin{array}{lrrrrr}\text { Absent } & 7 & (20) & 13 & (37.1) & 0.11 \\ \text { Present } & 28 & (80) & 22 & (62.9) & \end{array}$

Venous invasion

\begin{tabular}{|c|c|c|c|}
\hline Absent & 21 & (60) & $27(77.1)$ \\
\hline Present & 14 & (40) & $8(22.9)$ \\
\hline
\end{tabular}

Liver metastasis

\begin{tabular}{|c|c|c|}
\hline Absent & 31 (88.6) & 35 (100) \\
\hline Present & $4(11.4)$ & (0) \\
\hline
\end{tabular}

Peritoneal dissemination
Absent
25 (71.4) $32(91.4)$
$0.030^{\mathrm{b}}$
Present
10 (28.6) $3(8.57)$
Clinical stage

\begin{tabular}{llllll} 
I/II & 11 & $(31.4)$ & 23 & $(65.7)$ & $0.0037^{\mathrm{b}}$ \\
III/IV & 24 & $(68.6)$ & 12 & $(34.3)$ & \\
\hline
\end{tabular}

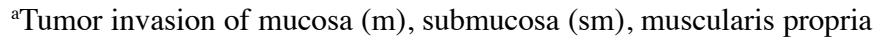
(mp), subserosa (ss), penetration of serosa (se), and invasion of adjacent strucures (si). ${ }^{\mathrm{b}} \mathrm{p}<0.05$. Exp., expression.

Transfection of microRNA-125a-3p precursor (Pre-miR ${ }^{T M}$ $125 a-3 p$ ). Using NUGC4, a gastric cancer cell line that expresses a high level of ERBB2 mRNA, either Pre-miR-125a-3p or Pre-miR negative control (Ambion ${ }^{\circledR}$ Pre-miR ${ }^{\mathrm{TM}}$ miRNA Precursors Applied Biosystems Japan Ltd.) was transfected at $30 \mathrm{nM}$ (final concentration) using Lipofectamine ${ }^{\mathrm{TM}}$ RNAiMAX (Invitrogen Life Technologies) according to the manufacturer's instructions. Pre-miR-125a-3p, the double-stranded precursor 


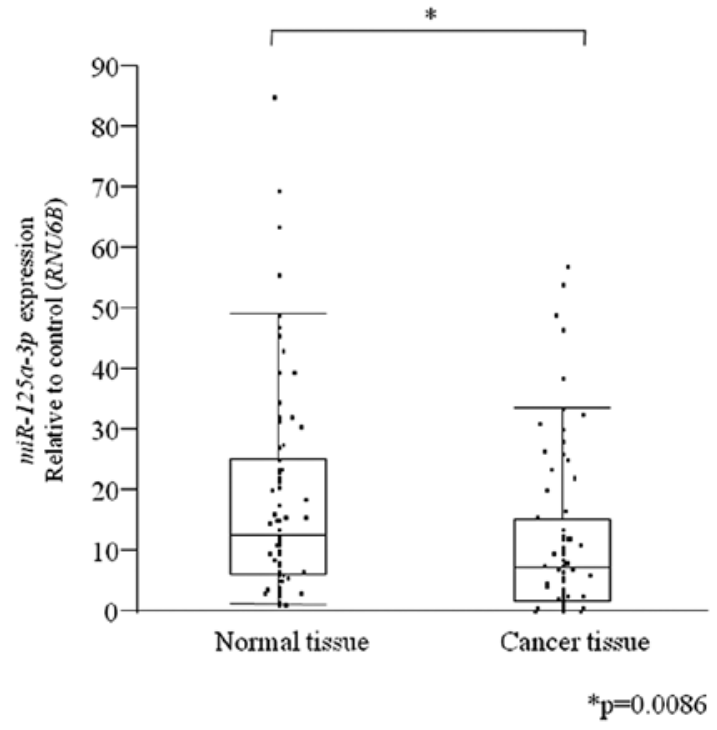

Figure 1. $m i R-125 a-3 p$ expression in paired cancer and normal samples from 70 gastric cancer cases analyzed by quantitative RT-PCR (dots, expression of each sample; horizontal line, median; box, 25th through 75th percentile; error bars, range).

microRNA product, produced only a functional $3 \mathrm{p}$ strand when introduced into cells.

\section{In vitro assays}

The 3-(4,5-dimethylthiazol-2-yl)-2,5-diphenyltetrazolium bromide (MTT) assay for gastric cancer cell growth after transfection with Pre-miR-125a. Logarithmically growing NUGC4 and MKN7 cells were transfected with Pre-miR-125a-3p or Pre-miR negative control and were seeded at $8.0 \times 10^{3}$ cells/well in 96-well flat-bottomed microtiter plates, in a final volume of $100 \mu \mathrm{l}$ of culture medium per well. Cells were incubated in a humidified atmosphere $\left(37^{\circ} \mathrm{C}\right.$ and $\left.5 \% \mathrm{CO}_{2}\right)$ for 24,48 , or $72 \mathrm{~h}$ after the initiation of transfection. The 3-(4,5-dimethylthiazol2-yl)-2,5-diphenyltetrazolium bromide (MTT) assay (Roche Diagnostics Corp.) was used to measure cell growth inhibition. After incubation, $10 \mu \mathrm{l}$ of MTT labeling reagent (final concentration of $0.5 \mathrm{mg} / \mathrm{ml}$ ) was added to each well, and the plate was incubated for $4 \mathrm{~h}$ in a humidified atmosphere. Solubilization solution $(100 \mu \mathrm{l})$ was added to each well, and the plate was incubated overnight in a humidified atmosphere. After confirming that the purple formazan crystals were completely solubilized, the absorbance of each well was measured by a Model 550 series microplate reader (Bio-Rad Laboratories), at a wavelength of $570 \mathrm{~nm}$ corrected to $655 \mathrm{~nm}$. The assay was performed using six replicates.

Statistical analysis. Data from RT-PCR analysis and in vitro transfection cell assays were analyzed with JMP 5. Overall survival rates were calculated actuarially according to the Kaplan-Meier method and were measured from the day of surgery. Differences between groups were estimated using the $\chi^{2}$ test, Student's t-test, repeated-measures ANOVA test, and the log-rank test. Variables with a value of $\mathrm{p}<0.05$ in univariate analysis were used in a subsequent multivariate analysis based on the Cox proportional hazards model. A probability level of 0.05 was chosen for statistical significance.

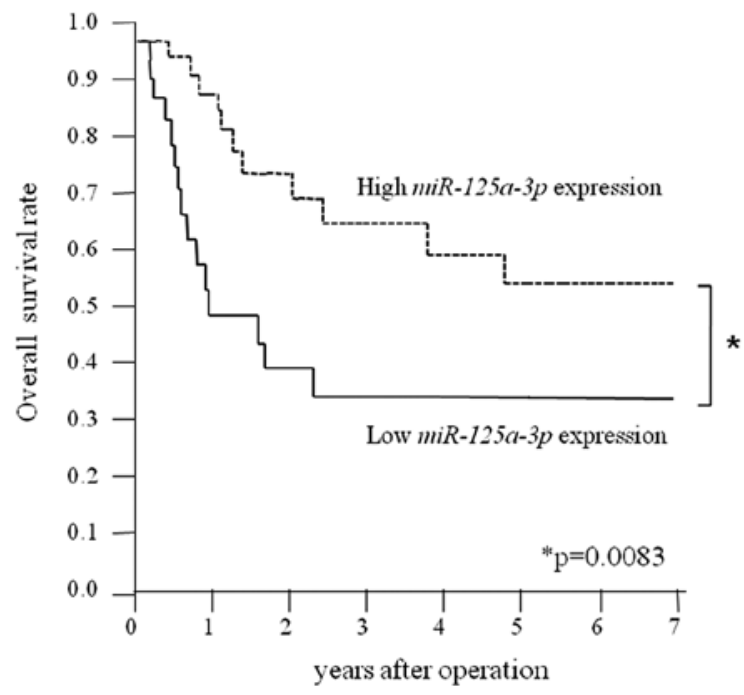

Figure 2. Kaplan-Meier overall survival curves of gastric cancer patients according to the level of $m i R-125 a-3 p$ expression. The high $m i R-125 a-3 p$ expression group $(n=35)$ was composed of patients with a higher than median ratio of expression (7.419, normalized to RNU6B); the low $m i R-125 a-5 p$ expression group $(n=35)$ exhibited a lower than median ratio.

\section{Results}

The clinicopathologic significance of miR-125a-3p expression in gastric cancer. The expression level of $m i R-125 a-3 p$ is significantly higher in normal tissue compared with paired cancerous tissue (Fig. 1). The 70 colon cancer cases were classified into two groups according to the median ratio of $m i R-125 a-3 p$ expression level (7.419, normalized to RNU6B) as determined by quantitative RT-PCR. Thirty-five cases were placed in the high expression group and 35 in the low expression group. The association between clinicopathological features and $m i R-125 a-3 p$ expression is summarized in Table I. In the low expression group, malignant potential such as tumor size, tumor invasion, lymph node metastasis, liver metastases, peritoneal dissemination, and clinical classification were enhanced compared to the high miR-125a-3p expression group $(\mathrm{p}<0.05)$. However, no significant differences were observed regarding age, gender, and histology. Univariate analysis identified $m i R-125 a-3 p$ expression, tumor invasion, lymph node metastasis, lymphatic invasion and venous invasion as prognostic factors for 5-year overall survival after surgery. Variables with a p-value $<0.05$ by univariate analysis were selected for multivariate analysis using Cox's proportional hazards model. miR-125a-3p expression [relative risk (RR): 1.796, confidence interval (CI): 1.16-2.87, $\mathrm{p}=0.0083$ ] was found to be a significant factor affecting 5-year overall survival after surgery (Table II). Analysis of the 5-year overall survival curves showed that patients in the low $m i R-125 a-3 p$ expression group had a significantly poorer prognosis than those in the high expression group $(\mathrm{p}<0.05)$ (Fig. 2).

miR-125a-5p expression is significantly associated with miR-125a-3p expression. To investigate both strands of mature miRNAs derived from precursor miR-125a, $m i R-125 a-5 p$ expression was also assayed in the same samples in which $m i R-125 a-3 p$ expression had been measured by RT-PCR 
Table II. Univariate and multivariate analysis of overall survival (Cox regression model).

\begin{tabular}{|c|c|c|c|c|c|c|}
\hline \multirow[b]{2}{*}{ Factors } & \multicolumn{3}{|c|}{ Univariate analysis } & \multicolumn{3}{|c|}{ Multivariate analysis } \\
\hline & $\mathrm{RR}$ & $95 \% \mathrm{CI}$ & p-value & $\mathrm{RR}$ & $95 \% \mathrm{CI}$ & p-value \\
\hline Age $(<65 />66)$ & 0.80 & $0.95-1.005$ & 0.10 & - & - & - \\
\hline Sex (male/female) & 0.085 & $0.54-1.28$ & 0.45 & - & - & - \\
\hline Histology grade (well, mod/poorly and others) & 1.39 & $0.96-2.08$ & 0.083 & - & - & - \\
\hline Depth of tumor invasion $(\mathrm{m}, \mathrm{sm}, \mathrm{mp} / \mathrm{ss}, \mathrm{se}, \mathrm{si})^{\mathrm{a}}$ & 2.67 & $1.79-4.16$ & $0.0001^{\mathrm{b}}$ & 2.61 & $1.67-4.30$ & $0.0001^{\mathrm{b}}$ \\
\hline Lymph node metastasis (negative/positive) & 4.39 & $2.01-18.6$ & $0.0001^{\mathrm{b}}$ & 4.24 & $1.60-19.6$ & $0.0015^{\mathrm{b}}$ \\
\hline Lymphatic invasion (negative/positive) & 2.53 & $1.38-6.32$ & $0.0011^{\mathrm{b}}$ & 1.26 & $0.45-2.69$ & 0.613 \\
\hline Venous invasion (negative/positive) & 1.65 & $1.13-2.43$ & $0.010^{\mathrm{b}}$ & 1.05 & $0.69-1.60$ & 0.818 \\
\hline miR-125a-3p expression (high/low) & 1.54 & $1.06-2.28$ & $0.023^{\mathrm{b}}$ & 1.80 & $1.16-2.87$ & $0.0083^{b}$ \\
\hline
\end{tabular}

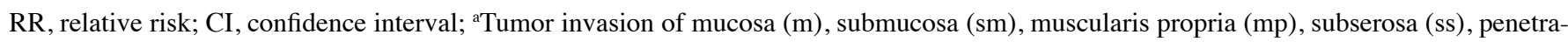
tion of serosa (se), and invasion of adjacent structures (si). ${ }^{\mathrm{b}} \mathrm{p}<0.05$.

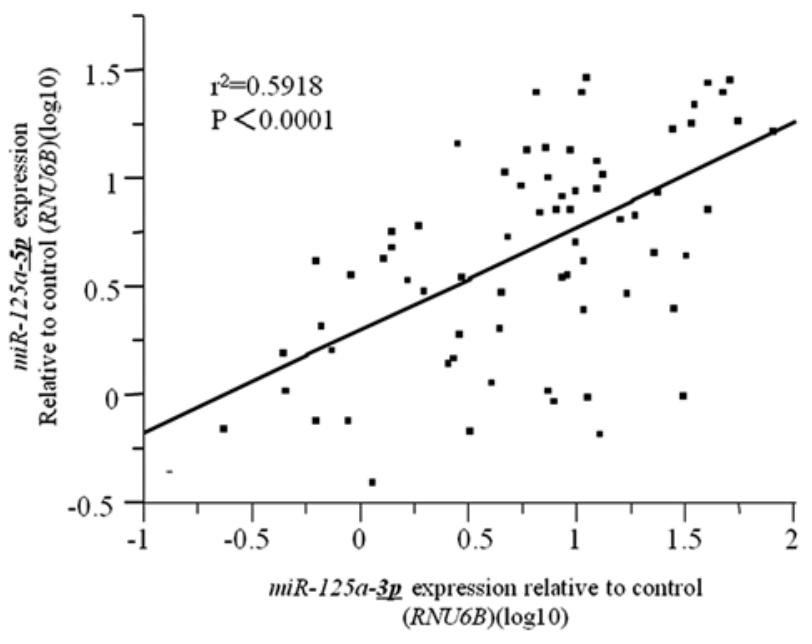

Figure 3. Correlation between the expression status of $m i R-125 a-3 p$ and $m i R-125 a-5 p$. The expression levels of $m i R-125 a-3 p$ and $m i R-125 a-5 p$ were highly correlated $\left(\mathrm{r}^{2}=0.5918, \mathrm{p}<0.0001\right)$.

analysis. The expression levels of the two mature of miRNAs were significantly correlated (Fig. $3, \mathrm{r}^{2}=0.5918$, p<0.0001).

miR-125a-3p inhibited the proliferation of gastric cancer cells. A proliferation assay was performed with parent cells, Pre-miR-125a-3p treated cells and negative control cells using two gastric cancer cell lines, MKN7 and NUGC4. The expression of $m i R-125 a-3 p$ in Pre-miR-125a-3p transfected cells was significantly higher than in parental and negative control pre-miR transfected cells (Fig. 4A, p<0.05). The assay confirmed that $m i R-125 a-3 p$ significantly suppresses the proliferative activity of gastric cancer cells in both cell lines (Fig. 4B).

\section{Discussion}

In this study, we show that miR-125a-3p expression is significantly associated with cancer progression and prognosis in human gastric cancer. $m i R-125 a-3 p$ is significantly down-regu- lated in gastric cancer tissues compared with corresponding normal tissues (Fig. 1). This finding suggests that $m i R-125 a-3 p$ is involved in gastric carcinogenesis. Clinicopathological analysis revealed that low $m i R-125 a-3 p$ expression contributes to more advanced tumor size, tumor invasion, lymph node metastasis, liver metastases, peritoneal dissemination, and poor prognosis (Table I, Fig. 2). Multivariate analysis revealed that $m i R-125 a-3 p$ is an independent prognostic factor for survival (Table II). These data suggest a tumor suppressive role for $m i R-125 a-3 p$ in gastric cancer.

The expression of $m i R-125 a-3 p$ is reportedly down-regulated in non-small cell lung cancer (19). In contrast, it is up-regulated in synovial sarcoma (20), and overexpression under hypoxic conditions in retinoblastoma has also been observed (21). $m i R-125 a-5 p$, the partner of $m i R-125 a-3 p$, is down-regulated in breast cancer (22-24), ovarian cancer (25), lung cancer (26), and medulloblastoma (27), indicating its tumor suppressive effect in human cancers. However, only a few reports have demonstrated a functional role for $m i R-125 a-3 p$, and this is the first describing the clinical significance of $m i R-125 a-3 p$ in gastrointestinal cancer.

In vitro studies revealed that $m i R-125 a-3 p$ suppresses the proliferation of gastric cancer cells. We previously demonstrated the same inhibitory effect of $m i R-125 a-5 p$ on cell proliferation. Therefore, these two mature miRNAs act similarly. Because these two strands are generated simultaneously from the same precursor, the expression levels of $m i R-125 a-3 p$ and $5 \mathrm{p}$ are significantly associated with each other (Fig. 3). RT-PCR showed that the two strands are equally expressed when normalized to an internal control, suggesting that both strands contribute to cellular function to the same extent. Jiang and colleagues previously demonstrated that $m i R-125 a-3 p$ and $m i R-125 a-5 p$ exert inverse effects on the invasion and migration of lung cancer cells (19), which is possible because each strand regulates a number of different target genes. Nevertheless, at least regarding the proliferation of gastric cancer cells, our data revealed that $m i R-125 a-3 p$ and $m i R-125 a-5 p$ work similarly to inhibit proliferation. The tumor suppressive effect of $m i R-125 a-3 p$ as well as $m i R-125 a-5 p$ leads to the conclusion that the functional role 

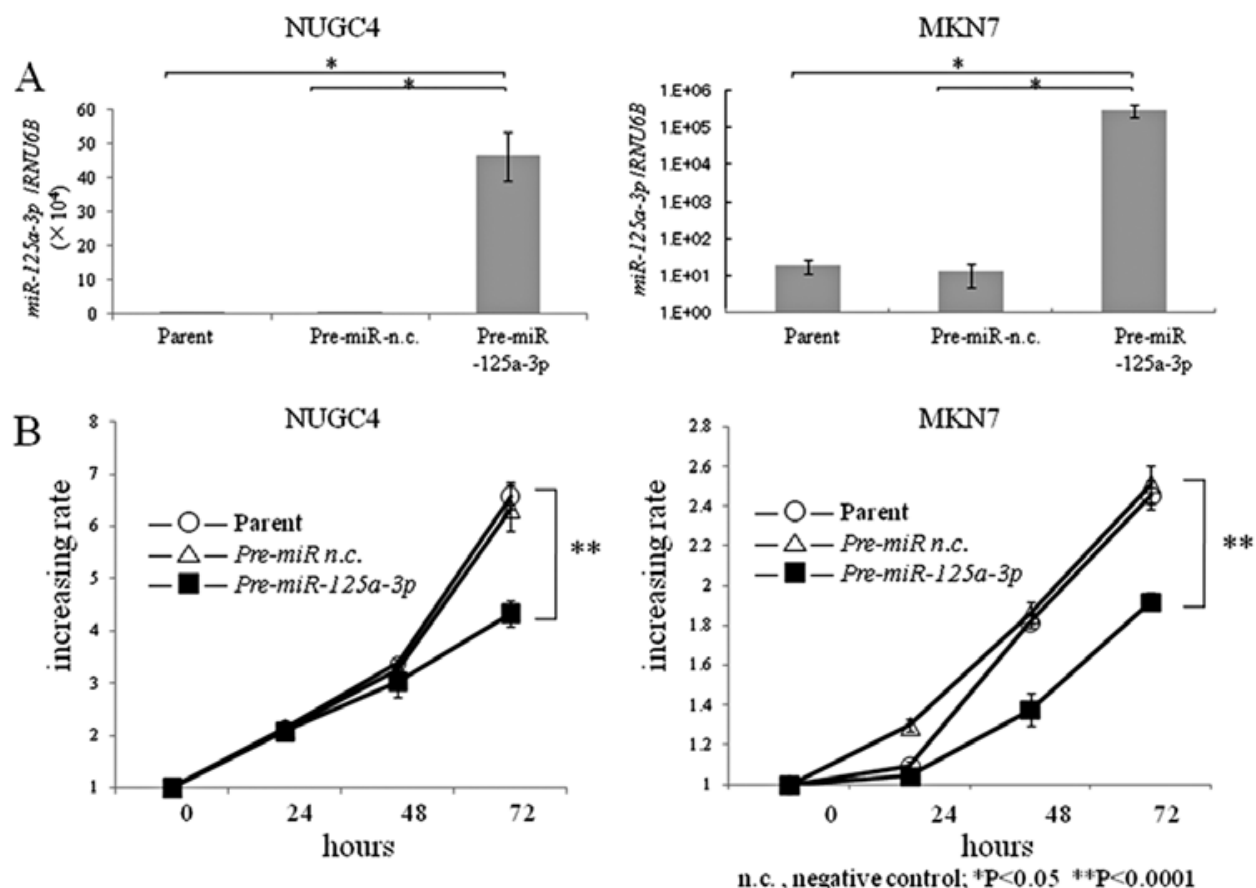

Figure 4. A, miR-125a-3p expression after treatment with negative control or Pre-miR-125a-3p in NUGC4 (left) and MKN7 (right) cells analyzed by quantitative RT-PCR. MiR-125a-3p expression in Pre-miR-125a-3p treated cells is significantly higher than in untreated cells (parent) and in Pre-miR negative control cells $(\mathrm{p}<0.05)$. The results are the mean \pm SD of triplicate experiments. B, miR-125a-3p inhibition of the proliferation of gastric cancer cell lines, NUGC4 (left) and MKN7 (right). Parental cells or cells transfected with Pre-miR-125a-3p or the Pre-miR-negative control transfected cells were seeded at $8.0 \times 10^{3}$ cells/well in 96 -well plates. Cell growth was monitored every $24 \mathrm{~h}$ using the MTT assay. Absorbance at $0 \mathrm{~h}$ was assigned a value of 1 . The results are the mean \pm SD of three replicates.

of another strand of mature form miRNA cannot be ignored, at least in miR-125a biogenesis.

Regarding miRNA therapy, some preclinical data suggest that a delivery system using adenovirus-associated vector (AAV) is reasonable for a strategy of tumor suppressive miRNA replacement (28). In this delivery system, restoring downregulated miRNA expression could be achieved by inserting genes coding for miRNAs into viral constructs $(28,29)$. Thus, the virus would ensure that both strands of individual miRNAs are equally transcribed. miRNAs for which the function of both mature forms are clearly defined, such as $m i R-125 a$, could be useful in obtaining an anti-proliferation effect of miRNA.

In conclusion, we demonstrated that $m i R-125 a-3 p$ is a meaningful prognostic marker in gastric cancer. Furthermore, $m i R-125 a$ mimic could be a novel therapeutic approach against gastric cancer.

\section{Acknowledgements}

We thank T. Shimooka, K. Ogata, M. Kasagi, and T. Kawano for their excellent technical assistance. This work was supported in part by the following grants and foundations: CREST, Japan Science and Technology Agency (JST); Japan Society for the Promotion of Science (JSPS) Grant-in-Aid for Scientific Research: 21679006, 20390360, 20590313, 20591547, 21591644, 21592014, 20790960, 21791297, 21229015, 20659209 and 20012039; New Energy and Industrial Technology Development Organization (NEDO) Technological Development for Chromosome Analysis; the Ministry of Education, Culture, Sports,
Science and Technology of Japan for Scientific Research on Priority Areas, Cancer Translational Research Project, Japan.

\section{References}

1. Boku N, Yamamoto S, Fukuda H, et al: Fluorouracil versus combination of irinotecan plus cisplatin versus S-1 in metastatic gastric cancer: a randomised phase 3 study. Lancet Oncol 10: 1063-1069, 2009.

2. Matsuda T, Marugame T, Kamo K, Katanoda K, Ajiki W and Sobue T: Cancer incidence and incidence rates in Japan in 2005: based on data from 12 population-based cancer registries in the Monitoring of Cancer Incidence in Japan (MCIJ) project. Jpn J Clin Oncol 41: 139-147, 2011.

3. Hamaguchi T, Shirao K, Ohtsu A, et al: A phase II study of biweekly mitomycin $\mathrm{C}$ and irinotecan combination therapy in patients with fluoropyrimidine-resistant advanced gastric cancer: a report from the Gastrointestinal Oncology Group of the Japan Clinical Oncology Group (JCOG0109-DI Trial). Gastric Cancer 14: 226-233, 2011.

4. Bang YJ, van Cutsem E, Feyereislova A, et al: Trastuzumab in combination with chemotherapy versus chemotherapy alone for treatment of HER2-positive advanced gastric or gastro-oesophageal junction cancer (ToGA): a phase 3, open-label, randomised controlled trial. Lancet 376: 687-697, 2010.

5. Esquela-Kerscher A and Slack FJ: Oncomirs - microRNAs with a role in cancer. Nat Rev Cancer 6: 259-269, 2006.

6 . Bartel DP: MicroRNAs: target recognition and regulatory functions. Cell 136: 215-233, 2009.

7. Nicoloso MS, Spizzo R, Shimizu M, Rossi S and Calin GA: MicroRNAs - the micro steering wheel of tumour metastases. Nat Rev Cancer 9: 293-302, 2009.

8. Spizzo R, Nicoloso MS, Croce CM and Calin GA: SnapShot: microRNAs in cancer. Cell 137: 586-586.e1, 2009.

9. Motoyama K, Inoue H, Mimori K, et al: Clinicopathological and prognostic significance of PDCD4 and microRNA-21 in human gastric cancer. Int J Oncol 36: 1089-1095, 2010 
10. Nishida N, Mimori K, Fabbri M, et al: MicroRNA-125a-5p is an independent prognostic factor in gastric cancer, and inhibits the proliferation of human gastric cancer cells in combination with trastuzumab. Clin Cancer Res 17: 2725-2733, 2011.

11. Ding L, Xu Y,Zhang W, et al: MiR-375 frequently downregulated in gastric cancer inhibits cell proliferation by targeting JAK2. Cell Res 20: 784-793, 2010.

12. Tsukamoto Y, Nakada C, Noguchi T, et al: MicroRNA-375 is downregulated in gastric carcinomas and regulates cell survival by targeting PDK1 and 14-3-3zeta. Cancer Res 70: 2339-2349, 2010.

13. Craig VJ, Cogliatti SB, Rehrauer H, Wundisch T and Muller A: Epigenetic silencing of microRNA-203 dysregulates ABL1 expression and drives Helicobacter-associated gastric lymphomagenesis. Cancer Res 71: 3616-3624, 2011.

14. Motoyama K, Inoue H, Nakamura Y, Uetake H, Sugihara K and Mori M: Clinical significance of high mobility group A2 in human gastric cancer and its relationship to let-7 microRNA family. Clin Cancer Res 14: 2334-2340, 2008.

15. Chiang HR, Schoenfeld LW, Ruby JG, et al: Mammalian microRNAs: experimental evaluation of novel and previously annotated genes. Genes Dev 24: 992-1009, 2010.

16. Yang JS, Phillips MD, Betel D, et al: Widespread regulatory activity of vertebrate microRNA* species. RNA 17: 312-326, 2011.

17. Japanese Gastric Cancer: A Japanese Classification of Gastric Carcinoma. 2nd English edition. Gastric Cancer 1: 10-24, 1998.

18. Mori M, Mimori K, Yoshikawa Y, et al: Analysis of the geneexpression profile regarding the progression of human gastric carcinoma. Surgery 131 (Suppl): 39-47, 2002.

19. Jiang L, Huang Q, Zhang S, et al: Hsa-miR-125a-3p and hsa-miR$125 \mathrm{a}-5 \mathrm{p}$ are downregulated in non-small cell lung cancer and have inverse effects on invasion and migration of lung cancer cells. BMC Cancer 10: 318, 2010.
20. Hisaoka M, Matsuyama A, Nagao Y, et al: Identification of altered microRNA expression patterns in synovial sarcoma. Genes Chromosomes Cancer 50: 137-145, 2011.

21. Xu X, Jia R, Zhou Y, et al: Microarray-based analysis: identification of hypoxia-regulated microRNAs in retinoblastoma cells. Int J Oncol 38: 1385-1393, 2011.

22. Guo X, Wu Y and Hartley RS: MicroRNA-125a represses cell growth by targeting HuR in breast cancer. RNA Biol 6: 575-583, 2009.

23. Li W, Duan R, Kooy F, Sherman SL, Zhou W and Jin P: Germline mutation of microRNA-125a is associated with breast cancer. J Med Genet 46: 358-360, 2009.

24. O'Day E and Lal A: MicroRNAs and their target gene networks in breast cancer. Breast Cancer Res 12: 201, 2010.

25. Nam EJ, Yoon H, Kim SW, et al: MicroRNA expression profiles in serous ovarian carcinoma. Clin Cancer Res 14: 2690-2695, 2008.

26. Wang G, Mao W, Zheng S and Ye J: Epidermal growth factor receptor-regulated miR-125a-5p - a metastatic inhibitor of lung cancer. FEBS J 276: 5571-5578, 2009.

27. Ferretti E, De Smaele E, Po A, et al: MicroRNA profiling in human medulloblastoma. Int J Cancer 124: 568-577, 2009.

28. Garzon R, Marcucci G and Croce CM: Targeting microRNAs in cancer: rationale, strategies and challenges. Nat Rev Drug Discov 9: 775-789, 2010.

29. Kota J, Chivukula RR, O'Donnell KA, et al: Therapeutic microRNA delivery suppresses tumorigenesis in a murine liver cancer model. Cell 137: 1005-1017, 2009. 